UDC 338.48

JEL Classification: M21

DOI: 10.15587/2312-8372.2018.146901

\section{Sokolenko A., Krainyuk L., Semernina T.}

\title{
IMPLEMENTATION OF THE SOMMELIER SERVICE AND ITS ROLE IN THE FINANCIAL PERFORMANCE IN THE RESTAURANT INDUSTRY OF UKRAINE
}

Об’єктом дослідження є впровадження послуг сомельє в заклади ресторанного господарства України. На практиці послуги сомельє в ресторанах України непоширені у порівнянні з країнами Західної Свропи. Проблема полягає у відсутності розуміння позитивного впливу впровадження послуг сомельє на фінансову діяльність закладів ресторанного господарства. Також відсутні дослідження щодо виявлення факторів впливу діяльності сомельє на дохід ресторану. Тому робота направлена на виявлення причин відсутності послуг сомельє в ресторанах України, а також на виявлення перспектив роботи сомельє для закладів ресторанного господарства.

Для вирішення основних дослідницьких завдань використовуються такі методи, як системний аналіз, структурування, діалектичний метод, теорія управління. За допомогою щих методів виявлені та описані негативні та позитивні наслідки послуг сомельє. Виявлено, що сомельє виконує обов'язки, які оптимізують операції ресторану, сприяє розвитку ресторанного бізнесу в цілому та насиченню ринка вин новими марками, а також підвищує задоволеність клієнтів та дохід ресторану.

В роботі розглянуто особливості поняття «сомельє», проаналізовано різновиди професї сомельє. Визначено, якими знаннями та вміннями повинен володіти сомельє, що дозволять йому якісно виконувати роботу. Деталізовано розглянуто функиї сомельє. Проаналізовано особливості роботи сомельє в ресторані. Досліджено питання перешкод впровадження послуги сомельє в ресторанах України. Також виявлено ряд переваг впровадження послуги сомельє в ресторанах. Доведено, що послуга сомельє також розглядається як коефіцієнт витрат, і його використання залежить від конщепиї бізнесу та очікувань гостей. Не дивлячись на позитивні аспекти впровадження роботи сомельє в ресторані, існує низька аргументів проти використання послуг сомельє.

Результати досліджень можуть бути використані дослідниками та експертами, які пращюють у ресторанному бізнесі. Врахування запропонованого підходу сприятиме забезпеченню високої ефективності інноваційної діяльності в ресторанній індустрї Украӥни.

ключові слова: особливості роботи сомельє, споживання вина, ресторанний бізнес, фінансові результати діяльності ресторанів.

\section{Introduction}

Consumption of wine in Ukraine has always been traditional, although most experts say that the culture of wine consumption in Ukraine is still undeveloped compared with the countries of Western Europe. While wine is becoming increasingly popular and consumers are more knowledgeable, the work of a sommelier continues to play an important role in certain better drinks available to meet the needs of customers. Given this issue, it is necessary to understand that the value and role of the work of sommeliers is very relevant. But nowadays there are no studies on the connection between the work of a sommelier and the financial results of the restaurant.

\section{The object of research and its technological audit}

The object of research is the introduction of sommelier services in restaurants of Ukraine. In practice, sommelier services in restaurants in Ukraine are rare in comparison with Western European countries. The problem lies in the lack of understanding of the positive impact of the introduction of sommelier services on the financial activities of restaurant establishments. There are also no studies on the identification of factors influencing the activities of sommeliers on restaurant income. Therefore, the work is aimed at identifying the reasons for the lack of sommelier services in restaurants in Ukraine, as well as at identifying prospects for sommeliers to work in restaurants.

\section{The aim and objectives of research}

The aim of research is studying the features of the sommelier as a professional wine seller. To achieve this aim it is necessary to perform the following objectives:

1. To conduct a study of the problems of developing a culture of wine consumption at a sommelier consultation.

2. To identify the reasons explaining the lack of sommelier services in the restaurant business.

3. To identify the factors influencing the activities of the sommelier on the income of the restaurant.

\section{Research of existing solutions of the problem}

Reflecting on the significance of sommeliers, the question arises whether this is actually necessary for the restaurant 
business. In [1], it is investigated that about half of the restaurants listed in the list of guilty viewers of the Gold Medal Winners chose the service of a sommelier or a special wine steward in their business. But in the author's work there are no studies regarding the features of the sommelier. For restaurants, the sale of wines is an important part of the revenue and can significantly increase profits. This is stated by the authors of the research [2, 3]. However, how employees, namely sommeliers, can bring more profit is not specified.

In addition, as the sale of wines has a significant contribution to the income of the restaurant, and staff training in the characteristics of wine tasting can be considered as a good investment for the restaurant. This is stated by the authors of $[4,5]$. However, the question remains how to conduct training of wine tasting specialists. The economic problems of the wine industry are studied in studies [6, 7]. But there is no consideration of the economic problems of the wine industry in the context of the development of the restaurant industry.

Works [8,9] are devoted to studies of the socio-economic and organizational problems of the development of public catering services in Ukraine. In these works, structural transformations of the catering system that occurred in the post-privatization period, features of the services of catering enterprises and their activities are investigated. However, they do not sufficiently reflect the current trends in the types of restaurant facilities and the prospects for their further development. And also the problems of the development of wine consumption culture are not considered at the consultation of a sommelier. The author of the work [10] emphasizes the importance of sommelier services in our time for the restaurant business. However, in this work there are no studies to identify deficiencies in the introduction of sommelier services.

Thus, the results of the analysis allow to conclude that the necessary studies on the impact of sommelier services specifically on the financial performance of the restaurant have not been studied. Also, there are no necessary studies aimed at identifying the reasons for the lack of sommelier services in restaurants in Ukraine, as well as at identifying the prospects for work of sommeliers for restaurants in Ukraine.

\section{Methods of research}

In the research process, the following methods were used: - monographic - when highlighted best practices in the development of the wine industry;

- abstract-logical - for theoretical generalizations of the research results, when generalizing and forming conclusions;

- statistical-economic - in determining the obstacles to the introduction of the profession of sommelier in Ukrainian restaurants.

\section{Research results}

In modern conditions, the role of services is constantly increasing. The number of subjects, employees in the service sector, the volume of products sold is constantly increasing. The concept of «service» includes a significant number of diverse activities. One of the types of services to consumers is the services of objects of restaurant economy [5]. Services that provide restaurants have common (like other types of services) and specific features. The current market of catering services is characterized by increased competition. For a more efficient operation, the owners of restaurants should make efforts to retain existing and win new customers. For this it is necessary to:

- introduce modern new forms and methods of management;

- produce new dishes and improve their quality;

- improve the quality of customer service;

- use modern equipment;

- respond quickly and flexibly to changing consumer needs, taking into account the specificity of the services of these particular objects, in order to become and remain unique.

There is a special group of restaurants where profits from the sale of alcoholic beverages are significant, and these are gastronomic restaurants. Gastronomic restaurants are restaurants that offer various dishes with a complex recipe in combination with fine alcoholic beverages [6]. The main concept of such restaurants is high cuisine and direct alcoholic beverages, offered by an individual recommendation of a sommelier. There are many definitions of the term «sommelier». Sommelier is a French word, which has no analogues in either English or Ukrainian, and therefore requires clarification. According to the definition proposed in [7], a sommelier is «the person responsible for serving drinks in a restaurant, who gives advice on choosing wines and drinks, who serves them or who watches their serving to the client until the moment it leaves restaurant».

A sommelier is the person responsible for serving drinks in a restaurant; it knows exactly which dishes with which drinks are best combined [8].

According to the authors of this work, today a sommelier is an expert with the skills of wine tasting, knowledge of its production, variety, storage, serving and combination with other beverages and dishes.

Sommelier is the image of the restaurant. The restaurant sommelier is the keeper of the wine cellar, the responsible specialist for the selection of wine for visitors. One of many important factors, in each country the duties of a sommelier are very different. For example, in Ukraine, in addition to serving guests of a restaurant, a sommelier periodically monitors suppliers of alcoholic beverages, thereby performing the functions of an administrator and in certain cases knows cash operations.

The profession of a sommelier is constantly at the stage of its development, and its direct connection with winemaking is gradually broken, expanding. Therefore, in many countries of the world the so-called tea, cheese, coffee sommeliers are appeared (Table 1).

Let's consider the functions of the sommelier. Its duties include:

- drawing up the restaurant's wine list and maintaining in accordance with it the stock of wines in the restaurant;

- take care of the wine cellar (or other place to store wine stocks);

- purchase of wine from suppliers or participation in the discussion of the order of the party;

- study of the market of wines and other alcoholic beverages;

- choice of suppliers (the main criterion - the ratio

of price and quality of wine);

- proposals for the choice of wine to guests and competent serving it to the table. 
Varieties of sommelier profession

Table 1

\begin{tabular}{|c|c|}
\hline Caviste & $\begin{array}{l}\text { This sommelier works in a wine cellar (or wine-gastonomic } \\
\text { boutique). Professional sommeliers training. The name of } \\
\text { the caviste comes from the french word "cave» - "cellar» }\end{array}$ \\
\hline $\begin{array}{l}\text { Cigar somme- } \\
\text { lier «fumellier» }\end{array}$ & $\begin{array}{l}\text { This is a cigar specialist who knows thoroughly cigars } \\
\text { and their combination with various alcoholic beverages }\end{array}$ \\
\hline Vitolie & $\begin{array}{l}\text { This is a consultant on varieties of cigars, their proper smo- } \\
\text { king and combination with drinks. The difference between } \\
\text { fumellier and vitolie is the same as in caviste and sommelier }\end{array}$ \\
\hline $\begin{array}{l}\text { Cheese } \\
\text { sommelier }\end{array}$ & $\begin{array}{l}\text { At the moment - this is only a service that was introduced } \\
\text { on the ships of one of the international cruise companies. It } \\
\text { organizes special tours for clients, they can use the advice } \\
\text { of experts on the Austrian Cheese Academy. «Fromagerie»- } \\
\text { there is no such term }\end{array}$ \\
\hline $\begin{array}{l}\text { Coffee } \\
\text { sommelier } \\
\text { «cap tester» }\end{array}$ & $\begin{array}{l}\text { This is a person who tastes and evaluates coffee. It deter- } \\
\text { mines the grade and country of origin of coffee by grain. } \\
\text { Evaluates ground coffee before it is filled with water and } \\
\text { after it is ready and gives an opinion on the finished drink }\end{array}$ \\
\hline $\begin{array}{l}\text { Tea sommelier } \\
\text { or tee tester }\end{array}$ & $\begin{array}{l}\text { This is a tea taster. It determines by color, smell and } \\
\text { taste - where it comes from, the variety, season of collec- } \\
\text { tion, method of storage and processing }\end{array}$ \\
\hline $\begin{array}{l}\text { Robat somme- } \\
\text { lier or «tasting } \\
\text { one left» }\end{array}$ & $\begin{array}{l}\text { The first robot sommelier, designed in Japan, it understands } \\
\text { wines almost like a real living professional, it determines the } \\
\text { brand of wine and the grape variety from which the drink is } \\
\text { made. Thanks to its infrared scanning system, it can «taste» } \\
\text { wines, cheeses and fruits. The growth of the "electronic } \\
\text { sommelier» the size of a bottle is about } 40 \text { centimeters. } \\
\text { It tries it with its left hand, which is a manipulator and is } \\
\text { equipped with a reading device, to which for tasting it is } \\
\text { necessary to bring a glass of wine }\end{array}$ \\
\hline $\begin{array}{l}\text { Japanese } \\
\text { telephone } \\
\text { sommelier }\end{array}$ & $\begin{array}{l}\text { This profession originated in Japan. We are talking about } \\
\text { experts in the field of mobile phones, in which new models } \\
\text { are difficult to understand. They regularly raise the level } \\
\text { of education and have special licenses. The duties of the } \\
\text { telephone sommelier include assistance in choosing a new } \\
\text { model, while it takes into account the financial capabilities of } \\
\text { the client and warns of the risks associated with the purchase }\end{array}$ \\
\hline
\end{tabular}

Note: built on the basis of [9]

However, the main task of the sommelier profession is preparation of a wine list, wine tasting and recommendations on the choice of drinks for guests of the restaurant. The tasks of the sommelier include not only knowledge of the types of beverages, characteristics, year, but also the ability to combine them with each other and with various dishes. There are features of the sommelier:

- psychologist (guess the mood of their clients, some-

times even determine their social status and origin);

- work in extreme conditions (in order to offer drinks

to ordered dishes, sommeliers usually have 2-3 minutes);

- mandatory completion of specialized courses of sommelier (know the technology of wine production, the versatility of grape varieties, the best years of its harvest, as well as the climatic conditions and geographical location of the vineyards themselves);

- should have a pleasant appearance, well-formulated speech, a sense of tact;

- have a perfect olfactory and taste memory;

- have the qualities of communication and honesty;

- have a good intuition;

- clearly assess the solvency of the guest and be able to offer the best of each price category;

- it is important to guess the passions of the guest and build a harmonious picture of the dinner, where the aperitif, accompaniment and digestif emphasize and complement each other.
In Ukraine, professional sommeliers are relatively few. Therefore, the profession of sommelier is considered to be in demand in the restaurant business. In the working moments in the Ukrainian sommelier has its own nuances. The obstacles to the introduction of the profession of sommelier in Ukrainian restaurants are analyzed:

- in Ukraine this profession is quite new, nowadays it is still at the stage of its formation;

- representatives of the profession in the majority of young people who are characterized by youthful maximalism, as well as self-confidence, which some employers consider a disadvantage. This prevents young professionals from continuing to learn and critically evaluate their professional knowledge in this area;

- not all Ukrainian visitors of restaurants serving gastronomic cuisine imagine the peculiarity of the sommelier profession;

- not all employers at the proper level assess workers in this area;

- Ukrainian specialists do not always have wine given enough freedom of action and, over time, their responsibilities are usually narrower than those of their foreign counterparts.

In the course of this research, the author analyzed how the role of sommeliers is perceived in modern conditions and how the quality of service provided to sommeliers influences the financial performance of a restaurant. Currently, the sommelier helps guests during the entire service, giving advice not only on the use of wine. It needs enough knowledge to combine drinks with dishes from the menu. The function of a sommelier can also be considered as a link between winemakers and consumers. It transmits information and history first, and ultimately sells wine. In carrying out this task, it can acquaint the guest with new winemakers.

A sommelier is also responsible for managing the wine cellar, checking stocks and ensuring the proper storage of food [2]. Wine is a delicate drink and if mistreated, it can disappear, leading to financial losses for the owner.

A number of advantages of introducing the services of sommeliers are revealed. A sommelier can increase the efficiency of working in a restaurant by creating a regular customer base, establish an auxiliary network with winemakers, and ultimately increase revenue. Introducing the latest methods and optimizing processes, it has a positive impact on the efficiency of the restaurant. A sommelier as a qualified employee can assist other colleagues in the restaurant, combine the duties of a sommelier with subsequent administrative and representative obligations, thus compensating for the problem with the number of staff. A sommelier is able to form a reputation for the restaurant, as the team leader as the first contact person, should respond in the event of complaints or complaints. It should have sufficient knowledge and social skills to solve such problems with the guests. Regardless of whether it is a financial or advertising factor, sommeliers increase profits on the account, reducing costs and increasing sales of wine. Untrained staff is simply not able to sell and advertise wine well enough. Therefore, a sommelier has the skills and experience to perform its duties well and therefore is able to generate higher incomes for the business.

Despite the positive aspects of introducing the work of a sommelier to a restaurant, there are low arguments against the use of sommelier services. The identified factors are divided into two zones: financial and productivity factors. Sommelier as an expert and human resource is a cost 
factor, especially for small restaurants. Sommeliers can also have a negative impact on the business due to their poor performance. Choosing the right person is the most important task of the restaurant owner. If the sommelier does not have sufficient knowledge and experience to perform tasks relating to storage, acquisitions and sales, then the service of the sommelier will not be profitable. Sommeliers can be intrusive, advise guests, not paying attention to their wishes and expectations. It is also always visible if a sommelier works too profit-oriented and recommends the most expensive wines, which will lead to the loss of customers. The use of sommelier services can be bad if it buys for too large amounts and without any control. This can lead to large stocks that are difficult to sell and thus turn into financial losses for the owner. If there is no control in the purchase it can lead to a financial catastrophe. Therefore, economical thinking should always be a priority.

\section{SWOT analysis of research results}

Strengths. The research results allow to point out such strengths for the introduction of the sommelier service, such as:

- development of innovations in the restaurant business, which allows the use of the latest equipment for sommelier services;

- modern high quality drinks;

- a wide range of foreign wines;

- opportunity to cooperate with EU countries in the supply of drinks in restaurants.

Weaknesses. The weak points for the introduction of the sommelier service are:

- image of the work of a sommelier is insufficiently formed;

- consumer ignorance of the culture of consumption of beverages;

- undeveloped marketing system.

Opportunities. The introduction of sommelier services provides such opportunities as:

- increase in sales, hence an increase in profits;

- gaining popularity of consumer culture;

- expanding the range of beverages in restaurants;

- opening of schools and scientific branches of the sommelier specialty.

Threats. Threats faced by a restaurant establishment when introducing a sommelier service:

- economic instability;

- increase in the number of competitors;

- uneconomical thinking sommelier;

- weak investment in the wine industry.

\section{Conclusions}

1. When studying the problems of developing a culture of wine consumption at a consultation with a sommelier, it is found that the culture of wine consumption among Ukrainians lags significantly behind that of Europe. The lack of development of a culture of wine consumption in Ukraine is mainly influenced by the following factors:

- myth is fixed that Ukraine is an Eastern country, which is characterized by the consumption of strong alcoholic beverages, such as vodka;

- underdevelopment of its own resource base;

- high cost of the final product due to the lack of own wine materials;
- high energy costs due to the lack of energy-saving technologies.

2. Upon detection of the reasons explaining the lack of sommelier services in the restaurant business, low arguments against the use of sommelier services were revealed, namely:

- financial factor and productivity factor;

- obsession of some sommeliers;

- uneconomical thinking.

3. Among the factors influencing the activity of a sommelier on the income of a restaurant, it is found that by creating a base of regular customers, a sommelier establishes a supporting network with winemakers, and ultimately increases incomes. Introducing the latest methods and optimizing processes, the sommelier is able to form a reputation for the restaurant, thereby contributing to an increase in the financial results of the restaurant.

The role of sommeliers has changed in recent decades. Its duties area is significantly reduced. Sommelier services can increase the number of winemakers and guests, reduce operating costs, and increase business efficiency and revenue generation.

\section{References}

1. Ben Dewald B. W. A. The role of the sommeliers and their influence on US restaurant wine sales // International Journal of Wine Business Research. 2008. Vol. 20, Issue 2. P. 111-123. doi: http://doi.org/10.1108/17511060810883740

2. Hughson A. L., Boakes R. A. The knowing nose: the role of knowledge in wine expertise // Food Quality and Preference. 2002. Vol. 13, Issue 7-8. P. 463-472. doi: http://doi.org/ 10.1016/s0950-3293(02)00051-4

3. An fMRI study on the influence of sommeliers' expertise on the integration of flavor / Pazart L. et. al. // Frontiers in Behavioral Neuroscience. 2014. Vol. 8. P. 358. doi: http://doi.org/ 10.3389/fnbeh.2014.00358

4. Gultek M. M., Dodd T. H., Guydosh R. M. Attitudes towards wine-service training and its influence on restaurant wine sales // International Journal of Hospitality Management. 2006. Vol. 25, Issue 3. P. 432-446. doi: http://doi.org/10.1016/ j.ijhm.2005.02.001

5. Arvisenet G., Guichard E., Ballester J. Taste-aroma interaction in model wines: Effect of training and expertise // Food Quality and Preference. 2016. Vol. 52. P. 211-221. doi: http:// doi.org/10.1016/j.foodqual.2016.05.001

6. Ralko O. S. Doslidzhennia vyrobnytstva ta spozhyvannia vyna v Ukraini // Intelekt XXI. 2014. Issue 6. P. 39-45.

7. Radchenko T. M. Ukraina $\mathrm{v}$ suchasnykh tendentsiiakh funktsionuvannia svitovoho rynku vyno produktsii // Naukovyi visnyk Mykolaivskoho derzhavnoho universytetu imeni V. O. Sukhomlynskoho. Seriia: Ekonomichni nauky. 2015. Issue 1. P. 70-76.

8. Traino V. M. Spetsyfika posluh obiektiv restorannoho hospodarstva // Naukovyi visnyk Poltavskoho universytetu ekonomiky i torhivli. 2010. Issue 5 (44). P. 149-155.

9. Worldwide Sommelier Association. URL: www.worldwidesommelier.com

10. Harris E. K. Customer Service: A practical approach (4th Edition ed.). Upper Saddle River: Pearson Prentice Hall, 2007.

Sokolenko Anna, Assistant, Department of Tourism and Hospitality Management, O. M. Beketov National University of Urban Economy in Kharkiv, Ukraine, ORCID: http://orcid.org/0000-0002-9271-7118, e-mail: sokolenko1802@gmail.com

Krainyuk Lyudmila, PhD, Professor, Department of Tourism and Hospitality Management, O. M. Beketov National University of Urban Economy in Kharkiv, Ukraine, ORCID: http://orcid.org/0000-00029655-5902, e-mail: Liudmyla.Krainiuk@kname.edu.ua

Semernina Tetyana, Department of Tourism and Hospitality Management, O. M. Beketov National University of Urban Economy in Kharkiv, Ukraine, ORCID: http://orcid.org/0000-0002-8537-7194 